\title{
Upregulation of fibronectin following loss of p53 function is a poor prognostic factor in ovarian carcinoma with a unique immunophenotype
}

Ako Yokoi ${ }^{1}$, Toshihide Matsumoto' ${ }^{1}$, Yasuko Oguri ${ }^{1}$, Yoshinori Hasegawa², Masataka Tochimoto', Mayu Nakagawa ${ }^{1}$ and Makoto Saegusa ${ }^{1 *}$

\begin{abstract}
Background: We previously demonstrated that ovarian high grade serous carcinomas (OHGSeCa) and ovarian clear cell carcinomas (OCCCa) with an HNF-1 $\beta+/$ p53+/ARID1A+ immunophenotype were associated with the worst unfavorable prognosis. To clarify the molecular mechanisms underlying this finding, we focused on alterations in the p53 signaling pathway in these tumors.

Methods: Changes in cell phenotype and function following knockdown of wild-type p53 (p53-KD) were assessed using OCCCa cells expressing endogenous HNF-1 $\beta$ and ARID1A. The prognostic significance of molecules that were deregulated following p53-KD was also examined using 129 OCCCa/OHGSeCa cases.

Results: p53-KD cells had increased expression of Snail, phospho-Akt (pAkt), and pGSK3 $\beta$, and decreased E-cadherin expression, leading to epithelial-mesenchymal transition (EMT)/cancer stem cell (CSC) features. The cells also exhibited acceleration of cell motility and inhibition of cell proliferation and apoptosis. Next generation sequencing revealed that fibronectin (FN) expression was significantly increased in the p53 KD-cells, in line with our observation that wild-type p53 (but not mutant p53) repressed FN1 promoter activity. In addition, treatment of OCCCa cells with FN significantly increased cell migration capacity and decreased cell proliferation rate, independent of induction of EMT features. In clinical samples, FN/p53 scores were significantly higher in OCCCa/OHGSeCa with the HNF-1 $\beta+/ p 53+/ A R I D 1 A+$ immunophenotype when compared to others. Moreover, high FN/high p53 expression was associated with the worst overall survival and progression-free survival in OCCCa/OHGSeCa patients.

Conclusion: These findings suggest that upregulation of FN following loss of p53 function may impact the biological behavior of OCCCa/OHGSeCa, particularly in tumors with an HNF-1 $\beta+/$ p53+/ARID1A+ immunophenotype, through alterations in cell mobility and cell proliferation. The accompanying induction of EMT/ CSC properties and inhibition of apoptosis due to p53 abnormalities also contribute to the establishment and maintenance of tumor phenotypic characteristics.
\end{abstract}

Keywords: Ovarian carcinoma, p53, HNF-1 $\beta$, ARID1A, Fibronectin, Prognosis, Immunophenotype, Cell proliferation, Cell mobility, Apoptosis

\footnotetext{
*Correspondence: msaegusa@med.kitasato-u.ac.jp

'Department of Pathology, Kitasato University School of Medicine, 1-15-1

Kitasato, Minami-ku, Sagamihara, Kanagawa 252-0374, Japan

Full list of author information is available at the end of the article
}

\section{$\triangle B M C$}

(c) The Author(s). 2020 Open Access This article is licensed under a Creative Commons Attribution 4.0 International License, which permits use, sharing, adaptation, distribution and reproduction in any medium or format, as long as you give appropriate credit to the original author(s) and the source, provide a link to the Creative Commons licence, and indicate if changes were made. The images or other third party material in this article are included in the article's Creative Commons licence, unless indicated otherwise in a credit line to the material. If material is not included in the article's Creative Commons licence and your intended use is not permitted by statutory regulation or exceeds the permitted use, you will need to obtain permission directly from the copyright holder. To view a copy of this licence, visit http://creativecommons.org/licenses/by/4.0/. The Creative Commons Public Domain Dedication waiver (http://creativecommons.org/publicdomain/zero/1.0/) applies to the data made available in this article, unless otherwise stated in a credit line to the data. 


\section{Background}

1Ovarian epithelial carcinomas (OECa) are among the most aggressive tumors and the leading cause of mortality among all types of malignancies in the female reproductive system [1]. Since the ovaries have a relatively inaccessible location and ovarian carcinoma patients very often lack symptoms in the early neoplastic stage, more than $75 \%$ of the patients are diagnosed with advanced stage disease that is characterized by metastasis to the peritoneal cavity [2]. In addition, approximately $80 \%$ of advanced stage patients have residual disease after surgery and receive front-line platinum-based combination chemotherapy; these individuals have a median progression-free survival (PFS) of 18 months [3].

p53 is widely acknowledged as the most frequently mutated gene in human malignancy and its mutational status is a prognostic marker in several tumor types [4]. Activated wild-type p53 (p53wt) acts as a checkpoint control for recognizing damaged DNA, allowing DNA repair and delayed entrance into the DNA replication phase of the cell cycle; together with observations that the incidence of tumorigenesis increases in p53 null or mutant tissues, these data confirm that p53 is a bona fide tumor suppressor [5]. Mutations in the TP53 gene are found in more than $50 \%$ of human malignancies and its inactivation can occur at various stages depending on the tissue that gives rise to the tumor. Therefore, loss of p53 function can promote neoplastic transformation as well as progression of established tumors to a more aggressive disease stage $[6,7]$. In OECa, and particularly in ovarian high-grade serous carcinomas (OHGSeCa), mutant p53 (p53mt) missense mutations are frequently found in the hotspot codon R175, R248, and R273 (http://www-p53.iarc.fr/) that are critical contact residues in the p53 DNA-binding domain. The mutations occur early during tumorigenesis, most likely in precursor lesions of OECa, highlighting the importance of p53mt as a driver of the malignancy [8-11].

We previously developed an effective immunoprofiling classification system for OECa using only 4 immunohistochemical markers (HNF-1 $\beta$, p53, ARID1A, and WT1) [12]. Using this system, we demonstrated that tumors with an HNF-1 $\beta+/$ p53+/ARID1A+ immunophenotype including OHGSeCa and ovarian clear cell carcinomas (OCCCa) were associated with the most unfavorable prognosis. In this study, we hypothesized that alterations in the p53 signaling pathway may play a key role in determining phenotypic characteristics in OECa with the HNF-1 $\beta+/ p 53+/ A R I D 1 A+$ immunophenotype. To test this, we set out to first examine the effects of knocking down p53wt (p53-KD) in OCCCa cells expressing endogenous HNF-1 $\beta$ and ARID1A. Next, we applied a next generation sequencing (NGS) assay to identify the molecules associated with loss of p53 function. Finally, we examined associations between molecules that were differentially expressed following p53-KD, tumor phenotypic characteristics and prognostic significance in OHGSeCa and OCCCa.

\section{Methods}

\section{Plasmids and cell lines}

The p53-specific short hairpin RNA (shRNA) oligonucleotides were designed as described previously [13]. Single-stranded p53 oligonucleotides were annealed and then cloned into BamH1-EcoRV sites of RNAi-Ready pSIREN-RetroQ vector (Takara, Shiga, Japan), according to the manufacturer's instructions. The p53mt (R248Q) was generated by PCR-based methods using a pCMVp53wt construct. The human Fibronectin 1 promoter (UCSC genome browser, https://genome.ucsc.edu/) between -2028 and -23 (where +1 represents the transcription start site) was also generated by PCR and was cloned into the pGL3B vector (Promega, Madison, WT, USA). The primer sequences for the PCR reaction used in this study are listed in Table 1. pCMV-p53wt, pGL3B- $(-1109 /+36)$ Snail luc, pGL3B- $(-899 /+47)$ HNF-1 $\beta$ luc, and pGL3B- $(-140 /+216)$ HNF-1 $\beta$ luc were also used as described previously [14-16].

Four OCCCa cell lines, OVISE, ES2, OVTOKO, and TOV-21G were used as described previously $[13,16$, 17], and two OHGSeCa cell lines, OVSAHO and OVCAR-3, were obtained from the National Institute of Biomedical Innovation (Osaka, Japan) and the American Type Culture Collection (Manassas, VA, USA), respectively. p53 shRNA knockdown cells were established using OVISE cells, which have a wild-type $p 53$ gene and abundant expression of endogenous HNF-1 $\beta$ and ARID1A (Supplementary Figure S1), as described previously $[13,17]$. In addition, spindle-shaped cells were defined as those that showed narrow and elongated phenotypes, along with weak or absent adhesions between cells, as described previously [17].

\section{Antibodies and reagents}

Anti-p53, anti-p21 waf1, anti-cyclin D1, and anti-bcl2 antibodies were purchased from Dako (Copenhagen, Denmark). Anti-HNF-1 $\beta$, anti-GSK-3 $\beta$, anti-Rb, antip27 ${ }^{\text {kip1}}$, anti-XIAP, anti-bax, and anti-integrin $\beta 1$ antibodies were obtained from BD Biosciences (San Jose, CA, USA). Anti-ARID1A, anti-cyclin B1, and anti-MDM2 antibodies were from Santa Cruz Biotechnology (Santa Cruz, CA, USA). Anti-Snail, anti-Akt, anti-phospho(p) Akt Serine473, anti-pGSK-3 $\beta$ Serine9, anti-pRb Serine807/811, anti-cleaved caspase-3, and anti-integrin $\beta 3$ antibodies were from Cell Signaling Technology (Danvers, MA, USA). Anti-fibronectin (FN), anti-E-cadherin, and anti- $\beta$ actin antibodies were obtained from Abcam (Cambridge, MA, USA), Takara (Shiga, Japan), and Sigma-Aldrich 
Table 1 Primer sequences used in this study

\begin{tabular}{|c|c|c|c|}
\hline Assay & Gene & & Sequence \\
\hline \multirow[t]{2}{*}{ shRNA } & p53 (position 775 to 794) & Forward & 5'-GATCCGGACTCCAGTGGTAATCTACTITCAAGAGAAGTAGATTACCACTGGAGTCTTाTाTG-3' \\
\hline & & Reverse & 5'-AATTCAAAAAAGACTCCAGTGGTAATCTACTTCTCTTGAAAGTAGATTACCACTGGAGTCCG-3' \\
\hline \multirow[t]{2}{*}{ Mutagenesis } & p53 mutant type (R248Q) & Forward & 5'-ATGAACCaGAGGCCCATCCTCACCATCATCA-3' \\
\hline & & Reverse & 5'-GGGCCTCtGGTTCATGCCGCCCATGCA-3' \\
\hline \multirow[t]{2}{*}{ mRNA } & Fibronectin 1 & Forward & 5'- CCATCGCAAACCGCTGCCAT-3' \\
\hline & & Reverse & 5'-AACACTTCTCAGCTATGGGCTT-3' \\
\hline \multirow[t]{2}{*}{ Promoter } & Fibronectin 1 (-2028 to -23$)$ & Forward & 5'-CGGCTAGCTTCAGTGCAGTAAATATATC-3' \\
\hline & & Reverse & 5'- ATCTCGAGTTATATGGGACGGTCCCCTCCCGCC-3' \\
\hline
\end{tabular}

Chemicals (St. Louis, MO, USA), respectively. Anti-cyclin A2 and anti-integrin $\beta 2$ antibodies were from Novocastra (Newcastle, UK) and Merck KGaA (Darmstadt, Germany), respectively. FN (catalog number \#F2006) and cisplatin (CDDP: \#479306) were purchased from Sigma-Aldrich Chemicals.

\section{Transfection}

Transfection was carried out using LipofectAMINE PLUS (Invitrogen, Carlsbad, CA, USA) as described previously [14-16]. Luciferase activity was assayed as described previously [14-16].

\section{Reverse transcription (RT)-PCR}

cDNA was synthesized from $2 \mu \mathrm{g}$ of total RNA. Amplification by RT-PCR was carried out in the exponential phase to allow comparison among cDNA synthesized from identical reactions using specific primers (Table 1). Primers for the $H N F-1 \beta$, Snail, and GAPDH genes were also applied, as described previously [14-16]. The signal intensity was analyzed by ImageJ software version 1.41 (NIH, Bethesda, MD, USA).

For quantitative analysis, real-time RT-PCR was also conducted using a Power SYBR Green PCR Master Mix (Applied Biosystems, Foster City, CA, USA). Fluorescent signals were detected using the ABI 7500 Real-time PCR System SDS Software (Applied Biosystems).

\section{Western blot assay}

Total cellular proteins were isolated using RIPA buffer [20 mM Tris- $\mathrm{HCl}$ (pH 7.2), 1\% Nonidet P-40, 0.5\% sodium deoxycholate, $0.1 \%$ sodium dodecyl sulfate]. Aliquots of the proteins were resolved by SDS-PAGE, transferred to membranes, and probed with primary antibodies, coupled with the ECL detection system (Amersham Pharmacia Biotechnology, Tokyo, Japan).

\section{Flow cytometry and Aldefluor assay}

Cells were fixed using 70\% alcohol and stained with propidium iodide (Sigma) for cell cycle analysis. Aldehyde dehydrogenase 1 (ALDH1) enzyme activity in viable cells was determined using a fluorogenic dye-based Aldefluor assay (Stem Cell Technologies, Grenoble, France) according to the manufacturer's instructions. The prepared cells were analyzed by flow cytometry using BD FACS Calibur (BD Biosciences) and CellQuest Pro software version 3.3 (BD Biosciences).

\section{Cell counting Kit-8 assay}

The quantitation of viable cell number in proliferation after CDDP treatment was carried out using a Cell Counting Kit-8 (CCK-8; Dojindo Lab, Kumamoto, Japan), according to the manufacturer's instructions.

\section{Wound healing assay}

Cells were seeded into 24-well tissue culture plates, and grown to reach almost total confluence. After a cell monolayer formed, a wound was scratched with a sterile 200- $\mu$ lip. The area of the wound was analyzed by ImageJ software version 1.41 (NIH). Cell migration parameters were calculated in pixels as wound closure.

\section{Migration assay}

Cell migration was determined using 24-well Transwell chambers with an $8-\mu \mathrm{m}$ pore size (Corning, NY, USA). The lower chamber was filled with medium containing $10 \%$ serum. Cell were suspended in serum-free medium with or without FN and transferred into the upper chamber. After $24 \mathrm{~h}$, the number of cells stained by hematoxylin-eosin (HE) on the bottom surface of the polycarbonate membranes was counted visually using a light microscope.

\section{Apoptotic index}

Apoptotic cells were identified in HE-stained sections, according to the criteria of Kerr et al. [18]. A total 10 fields were randomly selected, and the number of apoptotic cells was calculated by counting the mean number of apoptotic figures per high power field (HPF). 


\section{NGS assay}

Total RNAs were extracted from OV-shp53 and mock cells using the NucleoSpin RNA system (Takara). The concentration and quality of the RNA was verified with the Quantus Fluorometer (Promega) and Agilent 2100 Bioanalyzer, respectively. All the samples showed RIN values over 9. Total RNA (500 ng) was used for RNA library preparation, according to the instructions of the Quant Seq 3' mRNA-seq library preparation kit FWD from Illumina (Lexogen, Vienna, Austria). The libraries were PCR-amplified for 12 cycles.

Sequencing of the libraries (via single-end 75-bp reads) was conducted on the Illumina NextSeq500 system. All data analyses were conducted using Strand NGS (v3.2, Agilent Technologies). The adapter sequences were removed from the raw reads, and base trimming was performed from the 3' end of each read to remove bases with quality below Q10 up to a minimum length of $25 \mathrm{bp}$. Each read was mapped to the reference human genome hg38 with default settings. Expression patterns of transcripts were compared after normalization of DESeq [19] using default settings.

\section{TCGA data analysis}

The Cancer Genome Atlas (TCGA) OHGSeCa annotated TP53 gene alteration and mRNA expression data (RNA Seq V2 PSEM) for HNF-1 $\beta$ and ARID1A were extracted from cBioportal for Cancer Genomics (http:// www.cbioportal.org/) for 398 OHGSeCa cases.

\section{Clinical cases}

A total of 199 cases of OECa, surgically resected at Kitasato University Hospital between 2006 and 2017, were selected from our patient records according to the criteria of the 2014 World Health Organization classification [20]. All patients underwent oophorectomy with or without hysterectomy. None of the patients had received chemotherapy or any other preoperative treatment, while most patients had received Paclitaxel/Carboplatin-based chemotherapy after surgical treatment. Of these, 99 cases including 41 OHGSeCa and 58 OCCCa showed complete resection of the tumors, while 28 cases including $17 \mathrm{OHGSeCa}$ and 11 OCCCa had residual tumors after debulking surgery.

Evaluation of relapse and disease progression was conducted on the basis of radiologic image findings. The tumor cases investigated were comprised of 58 OHGSeCa, 9 ovarian low grade serous carcinoma, 29 ovarian endometroid carcinomas, 71 OCCCa, and 30 ovarian mucinous carcinomas. All tissues were routinely fixed in $10 \%$ formalin and processed for embedding in paraffin wax. Approval for this study was given by the Ethics Committee of the Kitasato University School of Medicine (B16-10).

\section{Immunohistochemistry (IHC)}

IHC was performed using a combination of the microwaveoven heating and polymer immunocomplex (Envision, Dako) methods, as described previously [14-16].

For evaluation of IHC findings, scoring of nuclear/ cytoplasmic immunoreactivity was performed, on the basis of the percentage of immunopositive cells and the immunointensity, with multiplication of values of the two parameters, as described previously [14-16]. In addition, FN/p53 score was generated by multiplication of the values of the two scores.

To evaluate the prognostic significance of FN and p53 expression, the scores were divided into two categories (high and low) with the mean values as the cut-off in each category (Table 2). With regard to p53, cases that

Table 2 Association between clinicopathological factors and Fibronectin and p53 IHC scores in OCCCa/OHGSeCa

\begin{tabular}{|c|c|c|c|c|c|c|c|c|}
\hline & & & \multicolumn{2}{|c|}{ Fibronectin IHCscore } & \multirow[b]{2}{*}{$p$-value } & \multicolumn{3}{|c|}{ p53 IHCscore } \\
\hline & & & $\operatorname{High}(\geqq 3)$ & $\operatorname{Low}(3<)$ & & High ( $\geqq 6)$ & Low $(6<)$ & $p$-value \\
\hline & & $n$ & n (\%) & n (\%) & & n (\%) & n (\%) & \\
\hline Age & $<58$ & 61 & $14(23.0)$ & $47(77.0)$ & 0.7 & $23(37.7)$ & $38(62.3)$ & 0.6 \\
\hline (years) & $\geqq 58$ & 66 & $12(18.2)$ & $54(81.8)$ & & $29(44.0)$ & $37(56.0)$ & \\
\hline Clinical & I & 40 & $7(17.5)$ & $33(82.5)$ & 0.7 & $4(10.0)$ & $36(90.0)$ & $<0.0001$ \\
\hline FIGO stage & II / III / IV & 87 & $19(21.8)$ & $68(78.2)$ & & $48(55.2)$ & $39(44.8)$ & \\
\hline \multirow[t]{2}{*}{ Histology } & OCCCa & 69 & $20(29.0)$ & $49(71.0)$ & 0.01 & $6(8.7)$ & $63(91.3)$ & $<0.0001$ \\
\hline & OHGSeCa & 58 & $6(10.3)$ & $52(89.7)$ & & $46(79.3)$ & $12(20.7)$ & \\
\hline Tumor size & $<11.2$ & 82 & $11(13.4)$ & 71 (86.6) & 0.01 & $41(50.0)$ & $41(50.0)$ & 0.008 \\
\hline (cm) & $\geqq 11.2$ & 45 & $15(33.3)$ & $30(66.7)$ & & $11(24.4)$ & $34(75.6)$ & \\
\hline LN & Positive & 27 & $11(40.7)$ & $16(59.3)$ & 0.008 & 15 (55.6) & $12(44.4)$ & 0.1 \\
\hline metastasis & Negative & 100 & $15(15.0)$ & 85 (85.0) & & $37(37.0)$ & $63(63.0)$ & \\
\hline Distant & Positive & 12 & $4(33.3)$ & $8(66.7)$ & 0.4 & $10(83.3)$ & $2(16.7)$ & 0.004 \\
\hline metastasis & Negative & 115 & $22(19.1)$ & $93(66.7)$ & & $42(36.5)$ & $73(63.5)$ & \\
\hline
\end{tabular}


were completely negative for p53 immunoreactivity were categorized into the high p53 score group (score $=12$ ), since combining $2 \mathrm{IHC}$ labeling patterns associated with p53 mutations ( $0 \%$ and $60-100 \%$ positive cells) correctly identified a mutation in $94 \%$ of cases [21].

\section{Statistics}

Comparative data were analyzed using the MannWhitney $U$-test. Overall survival (OS) was calculated as the time between onset and death or the date of the last follow-up evaluation. PFS was also examined from the onset of treatment until relapse, disease progression, or last follow-up evaluation. OS and PFS were estimated using the Kaplan-Meier methods, and the statistical comparisons were made using the log rank test. Univariate and multivariate analyses were performed using the Cox proportional hazards regression model. The cut-off for statistical significance was set as $p<0.05$.

\section{Results}

Loss of p53 function leads to induction of EMT features

To examine the phenotypic characteristics of OECa cells with the HNF-1 $\beta+/ p 53+/ A R I D 1 A+$ immunophenotype, we first established two independent cell lines in which p53 expression was blocked by a p53-specific shRNA (OV-shp53\#2 and \#8) using OVISE (OV) cells. The OVp53-KD cells showed increased expression of both HNF$1 \beta$ and ARID1A, in contrast to decreased expression of MDM2 and p21 ${ }^{\text {waf1 }}$, which are p53 target genes (Fig. 1a). $H N F-1 \beta$ mRNA expression was also increased in the OV-p53-KD cells as compared to the mock cells
(Fig. 1b), in line with the observation of dose-dependent repression of $H N F-1 \beta$ promoter activity following transfection of p53wt. In contrast, the repressive effects were not evident when p53mt was transfected (Fig. 1c).

The OV-p53-KD cells also demonstrated a significant switch towards a fibroblastic morphology (Fig. 2a), along with increased expression of Snail, pAkt, and pGSK-3 $\beta$, and decreased E-cadherin expression (Fig. 2b). Although Snail promoter activity was inhibited by p53wt, but not p53mt (Fig. 2c), changes in mRNA expression were relatively minor in OV-p53-KD cells as compared to the mock cells (Fig. 2d). These findings suggest that loss of p53 function contributes to increased expression of HNF-1 $\beta$ and ARID1A, leading to induction of epithelialmesenchymal transition (EMT) features, probably through post-translational regulation of Snail expression.

\section{Loss of p53 function is associated with CSC features and acceleration of cell mobility}

To examine whether p53-KD affects cell proliferation, the two independent OV-p53-KD cell lines were seeded at low density. OV-p53-KD cells tended to proliferate more slowly, particularly in the exponential growth phase, along with an increased proportion of cells in G2/ $M$ phase of the cell cycle (Fig. 3a). To further examine alterations in expression of several cell cycle-related molecules during cell growth, the OV-p53-KD cells were rendered quiescent by serum starvation and were subsequently stimulated with serum. At 6,12 , and $24 \mathrm{~h}$ after release into the cell cycle, p $27^{\text {kip } 1}$ expression was substantially increased in OV-p53-KD cells relative to the

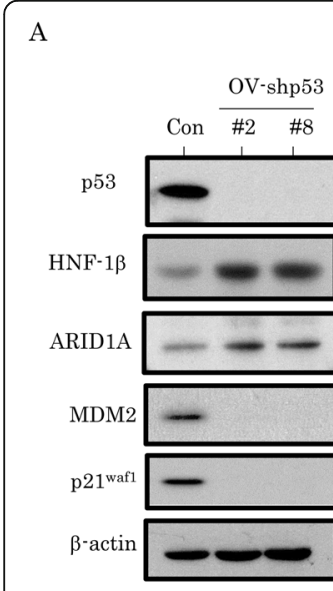

B

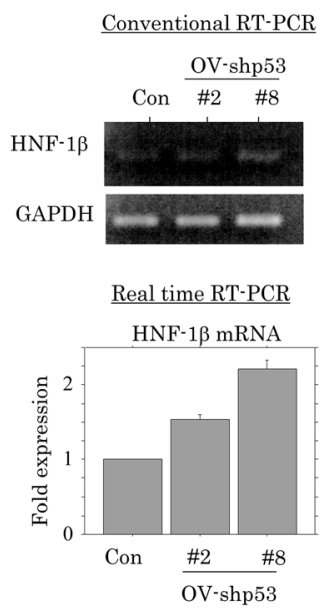

C
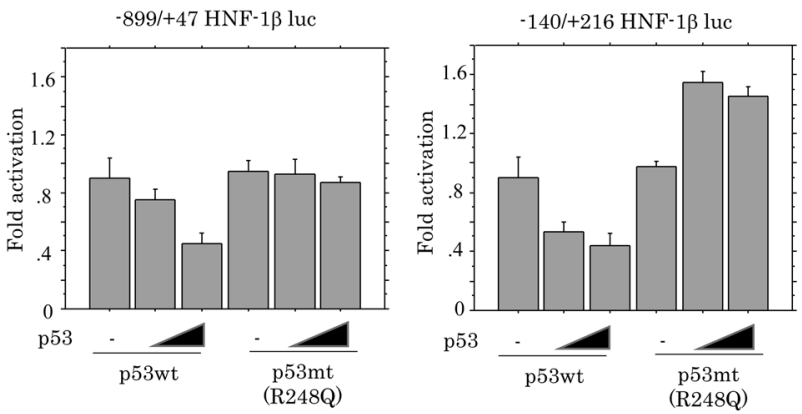

Fig. 1 Expression of HNF-1 $\beta$ and ARID1A in p53-KD cells. a Western blot analysis for the indicated proteins in total lysates from OV-shp53 and control cells (Con). b Analysis of endogenous HNF-1 $\beta$ mRNA expression by conventional (upper) and real time RT-PCR assay (lower) for OV-shp53 and control cells (Con). The fold changes in mRNA expression detected by real time RT-PCR are presented as means \pm SDs. The experiment was performed in triplicate. c OVISE cells were transfected with two HNF-1 $\beta$ reporter constructs, respectively, together with either p53wt or p53mt. Relative activity was determined based on arbitrary luciferase light units normalized to pRL-TK activity. The activities of the reporter plus the effector relative to that of the reporter plus empty vector are shown as means \pm SDs. The experiment was performed in duplicate 


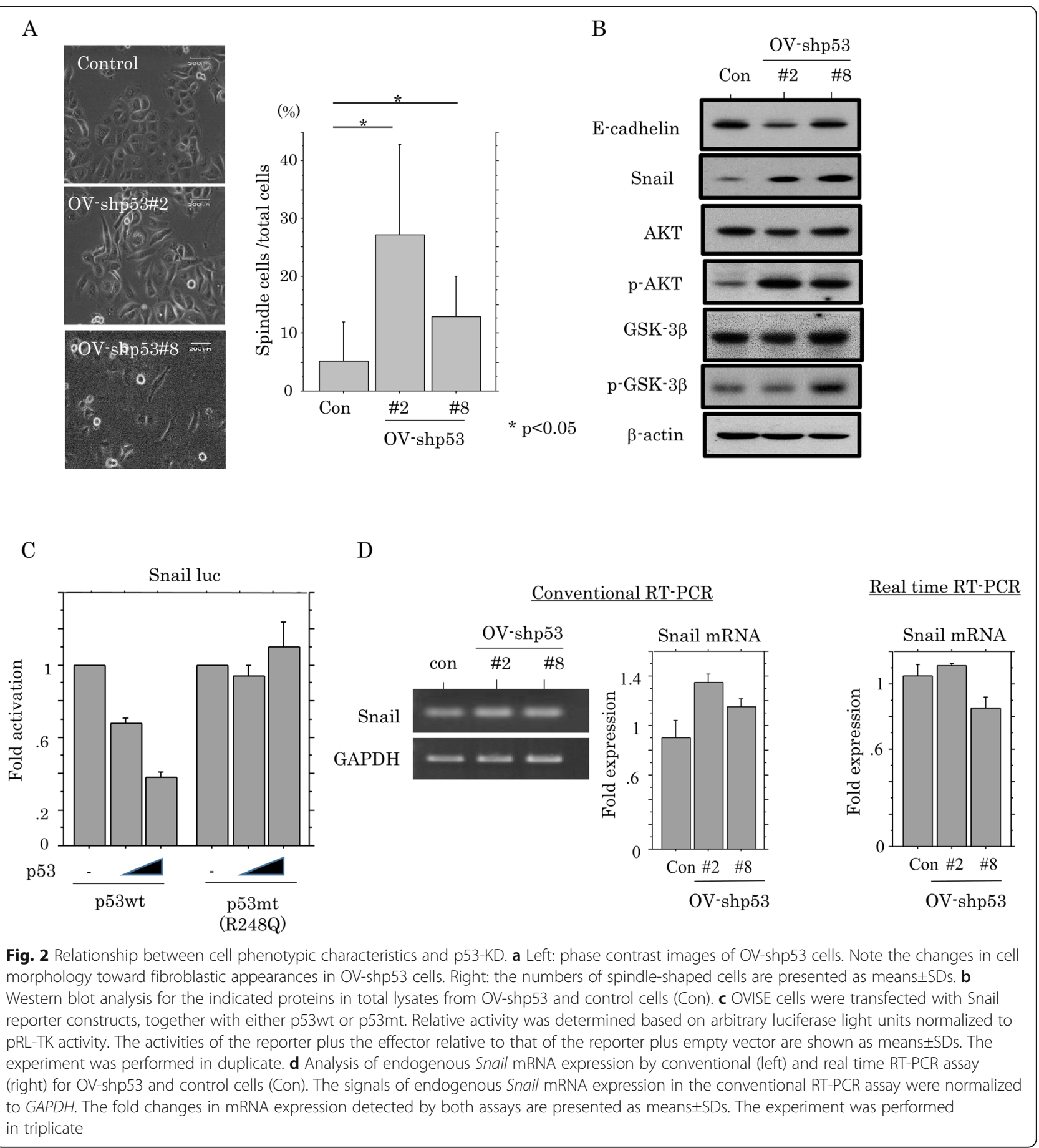

mock cells, in contrast to the progressive reduction of cyclin B1 expression in the former (Fig. 3b).

Next, we examined the association between loss of p53 function and apoptotic features in response to cytotoxic effects. Treatment of OV-p53-KD cells with CDDP showed decreased apoptotic cells as compared to the mock (Fig. 3c), in line with the results of increased cell viability during CDDP treatment (Fig. 3d). The expression of cleaved caspase-3, as well as bax and bcl-2, were also apparently decreased in the OV-p53-KD cells as compared to mock cells, in contrast to increased pAkt, but not XIAP, expression (Fig. 3e).

Since EMT promotes stem cell properties and further generates cells with cancer stem cell (CSC)-like features [22], we examined the association between loss of p53 function and CSC properties. As shown in Fig. 4a, there was a significant increase in the ALDH ${ }^{\text {high }}$ population, 


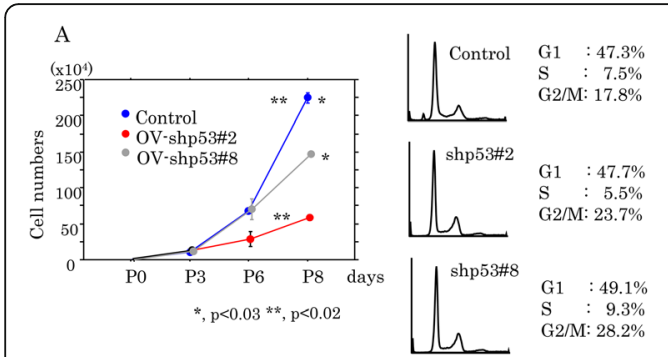

B

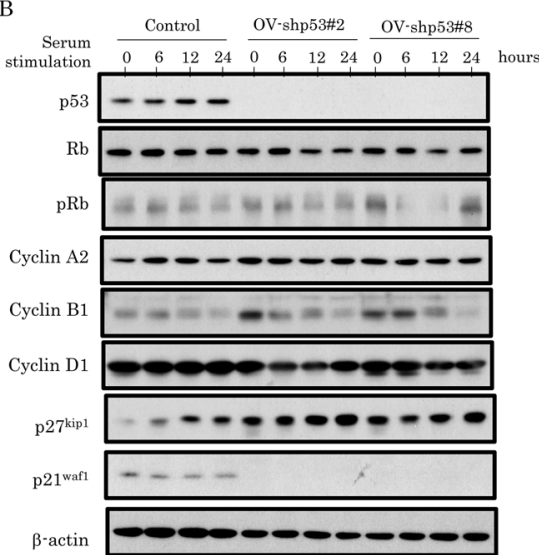

C
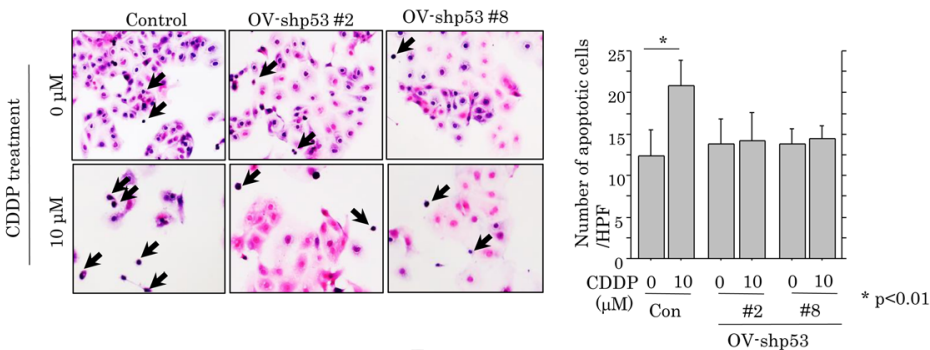

D

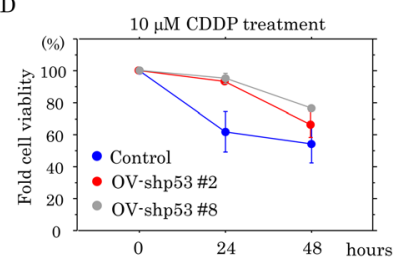

E ov-

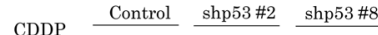

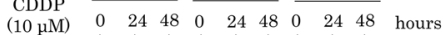
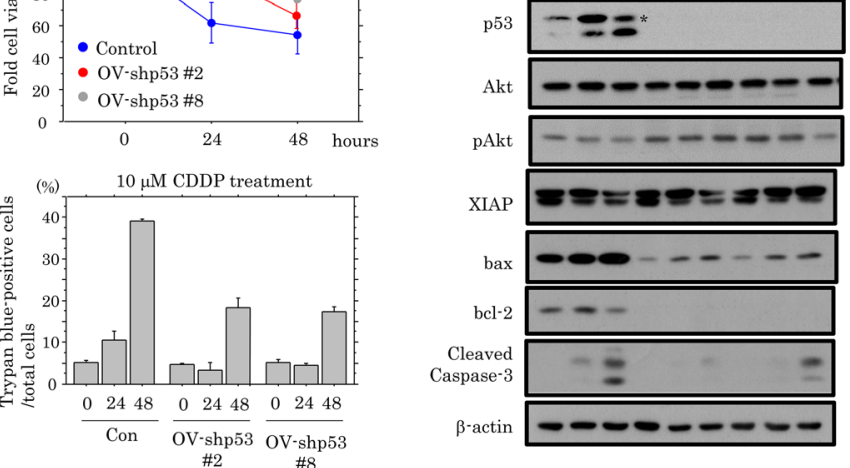

\#8

Fig. 3 Relationship between p53-KD and cell proliferation or apoptosis. a Left: two independent OV-shp53 and control cell lines were seeded at low density. The cell numbers are presented as means \pm SDs. P0, P3, P6, and P8 are 0, 3, 6, and 8 days after seeding, respectively. Right: FACS analysis of OV-shp53 and control cells at 3 days after seeding (P3). b Western blot analysis for the indicated proteins in total lysates from OVshp53 and the mock cells. c Left: after treatment with $10 \mu \mathrm{M}$ CDDP, OV-shp53 and control cells undergoing apoptosis are indicated by arrows. Original magnification, $\times 400$. Right: the numbers of apoptotic cells are demonstrated as means \pm SDs. Con, control. $d$ Upper: treatment of OVshp53 and control cells with $10 \mu \mathrm{M}$ CDDP for the times shown. Cell viability was measured using the CCK-8 kit. The viability in the absence of CDDP treatment $(0 \mathrm{~h})$ is set as 100\%. Lower: treatment of OV-shp53 and control cells with $10 \mu \mathrm{M}$ CDDP for the times shown. The numbers of trypan blue-positive cells (non-viable cells) are presented as mean \pm SD. This experiment was performed in triplicate using independent samples. e Western blot analysis for the indicated proteins in total lysates from OV-shp53 and control cells treated with $10 \mu \mathrm{M}$ CDDP

which includes a high percentage of CSC-like cells, in the p53-KD cells compared to the mock cells.

To further examine whether loss of p53 function contributes to cell motility, we carried out scratch and migration assays. The OV-p53-KD cells refilled wounded empty spaces more rapidly (Fig. 4b), in line with the significantly increased migration rates as compared to the mock cells (Fig. 4c). These findings suggest that loss of p53 function also engenders CSC features and accelerates cell motility in OVISE cells; these changes are accompanied by inhibition of cell proliferation and susceptibility to apoptosis.

\section{Upregulation of FN expression by loss of p53 function}

To identify genes that are differentially expressed following $\mathrm{p} 53-\mathrm{KD}$, NGS assays were carried out using total RNAs extracted from OV-p53-KD cells. A total of 12, 051 and 13,094 genes in OV-shp53\#2 and OV-shp53\#8 cells were dysregulated, respectively. Of these, 57 and 83 genes were upregulated or downregulated over 5-fold, respectively, in the $\mathrm{p} 53-\mathrm{KD}$ cells as compared to the mock cells. As shown Fig. 5a, hierarchical clustering revealed that the genes could be readily categorized into eleven groups, and we focused on the FN1 gene in group IV that was overexpressed by 17 -fold. FN1 mRNA and protein expression were apparently increased in OVp53-KD cells, along with increased expression of integrin $\beta 1, \beta 3$, and $\beta 3$ (Fig. 5b, c). Moreover, FN1 promoter activity was repressed by transfection of p53wt, but not p53mt (Fig. 5d).

Since FN is an EMT-related marker [23, 24], we asked whether there was an association of FN with either EMT or cell motility. OVISE cells treated with FN did not show any changes in cell morphology or expression of E-cadherin, Snail, Akt and GSK-3 $\beta$ (Fig. 6a); the expression of apoptosis-related molecules was also unchanged (Fig. 6b). In contrast, both scratch and migration assays revealed that FN treatment resulted in a significant increase in migration capacity (Fig. 6c,d), along with a decrease in proliferation at later stages (Fig. 6e). These findings suggest that FN is an important determinant of cellular function in p53-KD cells due to its effects on cell 


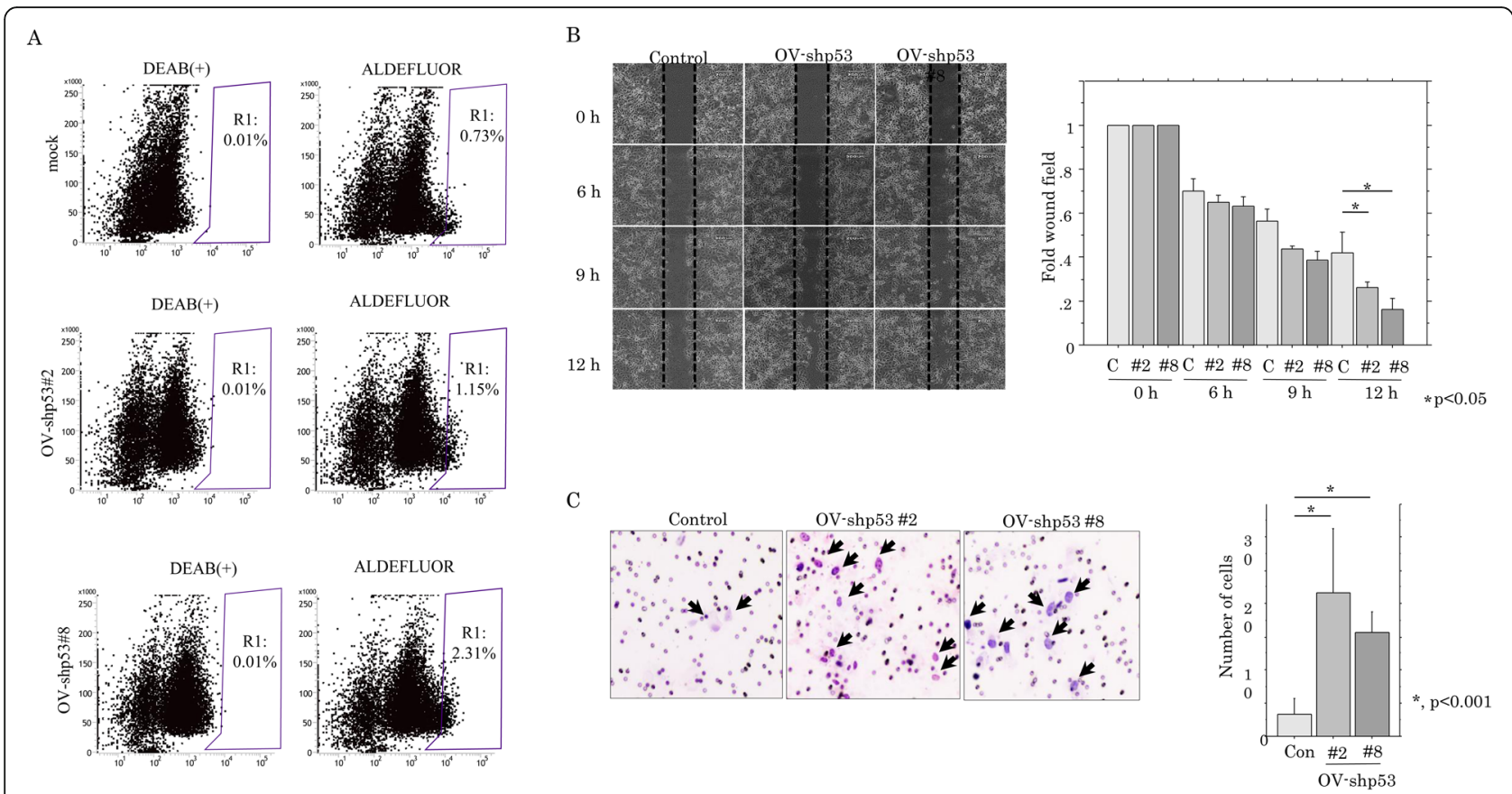

Fig. 4 Relationship between p53-KD and cancer stem cell features or cell migration. a Aldefluor analysis in OV-shp53 and control cells. Note the R1 populations including the ALDH ${ }^{\text {high }}$ population with cancer stem cell-like features. b Left: wound-healing assay with OV-shp53 and control cells. A scratch 'wound' was introduced to the middle of wells containing cell growth to confluency, and phase contrast images were taken after 6, 9, and $12 \mathrm{~h}$. Right: the values of wound areas in $0 \mathrm{~h}$ were set as 1 . The fold wound areas are presented as means \pm SDs. C, control. c Migration rate measured using transwell assay. Left: the OV-shp53 and control cells were seeded in a 24-well transwell plates and incubated for $24 \mathrm{~h}$ in medium without serum. Cells were stained with HE and counted using a light microscope. Right: the numbers of migrated cells are presented as means \pm SDs

mobility and proliferation, rather than via modulation of EMT or apoptosis.

\section{Prognostic significances of $\mathrm{FN}$ and $\mathrm{p} 53$ expression in OCCCa/OHGSeCa}

Representative IHC findings for FN and p53 in OCCCa and OHGSeCa are illustrated in Fig. 7a, demonstrating cytoplasmic immunostaining for FN and nuclear staining for p53. FN score was significantly higher in OCCCa as compared to that of $\mathrm{OHGSeCa}$, in contrast to a significantly higher p53 score in the latter (Supplementary Figure S2A). Previously, we used hierarchical clustering analysis to identify seven immunopurified groups (IPGs) in OECa including OCCCa, OHGSeCa, OLGSeCa, $\mathrm{OEmCa}$, and $\mathrm{OMuCa}$ [12]. Here, we observed that average FN/p53 scores were significantly higher in IPG VII, which includes OCCCa/OHGSeCa with the HNF-1 $\beta+/ p 53+/ A R I D 1 A$ immunophenotype, and lower in the IPGs IV, V, and VI (Fig. 7b). Similar findings were also observed in p53, but not $\mathrm{FN}$, scores among IPGs including the five OECa histotypes (Supplementary Figure S2B).

The FN scores were also significantly associated with tumor histotype, tumor size, and lymph node metastasis in OCCCa; p53 score was also significantly correlated with clinical stage, histotype, tumor size, and distant metastasis in OHGSeCa (Table 2).

The Kaplan-Meier curves showed that patients with high FN and p53 scores had poorer OS and PFS when compared to patients with low scores in the OCCCa/ OHGSeCa category (Fig. 8a, b), although such associations were not observed in p53 scores in OHGSeCa (Supplementary Figure S3). Patients with a combination of high FN and high p53 scores also had the worst OS and PFS in OCCCa/OHGSeCa, whereas patients with low values of both scores had the best prognosis (Fig. 8c).

Univariate Cox progression hazards regression revealed that FN, p53, age, tumor histotype, FIGO stage, lymph node metastasis, distant metastasis, and residual tumors after surgical treatment were significant prognostic factors for OS or PFS in OCCCa/ OHGSeCa. In addition, multivariate Cox regression analysis showed that FN, FIGO stage, and distant metastasis were significant and independent prognostic factors for OS or PFS (Table 3). These findings suggest that a combined IHC analysis of FN and p53 expression is useful for prognostic prediction of OCCCa/OHGSeCa. 


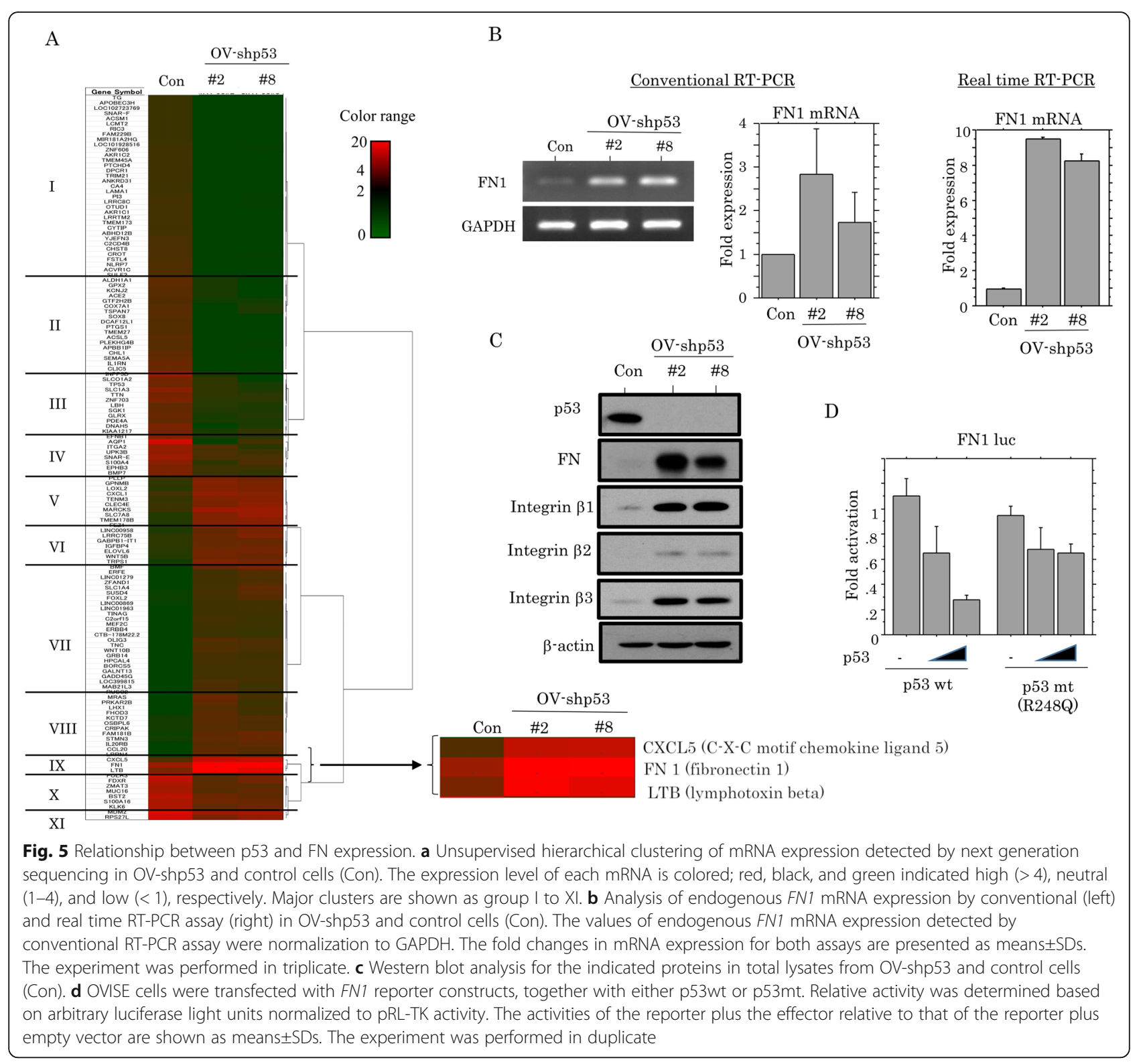

\section{Discussion}

Although extensive studies on the gain-of-function (GOF) effects of p53mt have been conducted using in vitro cell culture systems, several in vivo models have indicated that the primary effect of p53 mutation is the loss of p53wt function, with little or no GOF effect on tumorigenesis. Thus, the GOF of a particularly p53mt is likely to be determined by tissue- and tumor type-specific factors. For example, MMTV-HrasTP53 $3^{R 172 H / R 172 H}$ and MMTVHras $/ \mathrm{TP} 53^{-/-}$mice were very similar with regard to age of salivary tumor onset, tumor growth rate, tumor histopathological features, and response to a DNA-damaging agent [25]. This was also the case in a $K$-ras-driven lung cancer model, as well as in the context of WAP-Cre-induced expression of the p53R270H mutant in p53-null- mouse mammary glands, and in p53R172H homozygous knock-in mouse models [26-28]. In addition, the GOF activity of any particular p53mt is largely dependent on multiple signals required for its post-translational stabilization: the presence of such signals is likely to vary among both normal and tumor cells [29]. Based on the above evidence, we examined alterations in the p53 signaling pathway using cells following shRNA-mediated knockdown of p53wt.

Here, we provide clear evidence that p53 loss leads to upregulation of HNF-1 $\beta$, as well as ARID1A, at both mRNA and protein levels in OCCCa cells. Moreover, transfection of $\mathrm{p} 53 \mathrm{wt}$, but not $\mathrm{p} 53 \mathrm{mt}$, represses $H N F-1 \beta$ promoter activity, suggesting that alterations in the $p 53$ gene may play an important role in development of 

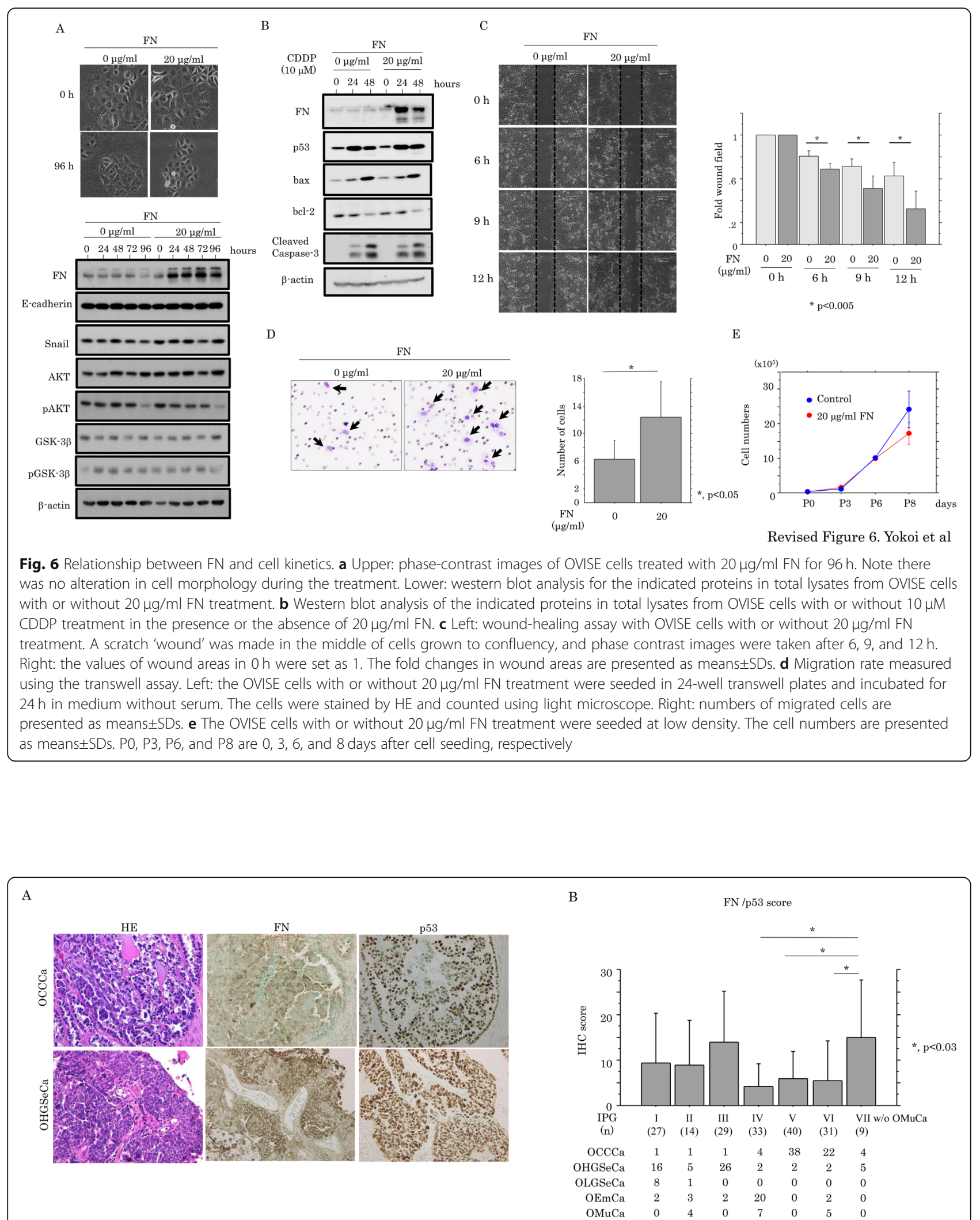

Fig. $7 \mathrm{HC}$ findings in serial sections of OCCCa and OHGSeCa tumors (a) Staining by HE and IHC staining for the indicated proteins in OCCCa and OHGSeCa. Original magnification, $\times 100$. (b) FN/p53 IHC scores in the immunoprofile groups (IPGs) of OECa including OCCCa, OHGSeCa, OLGSeCa, OEmCa, and OMuCa. OMuCa are excluded from IPG VII (w/o OMuCa). The data shown are as means \pm SDs 

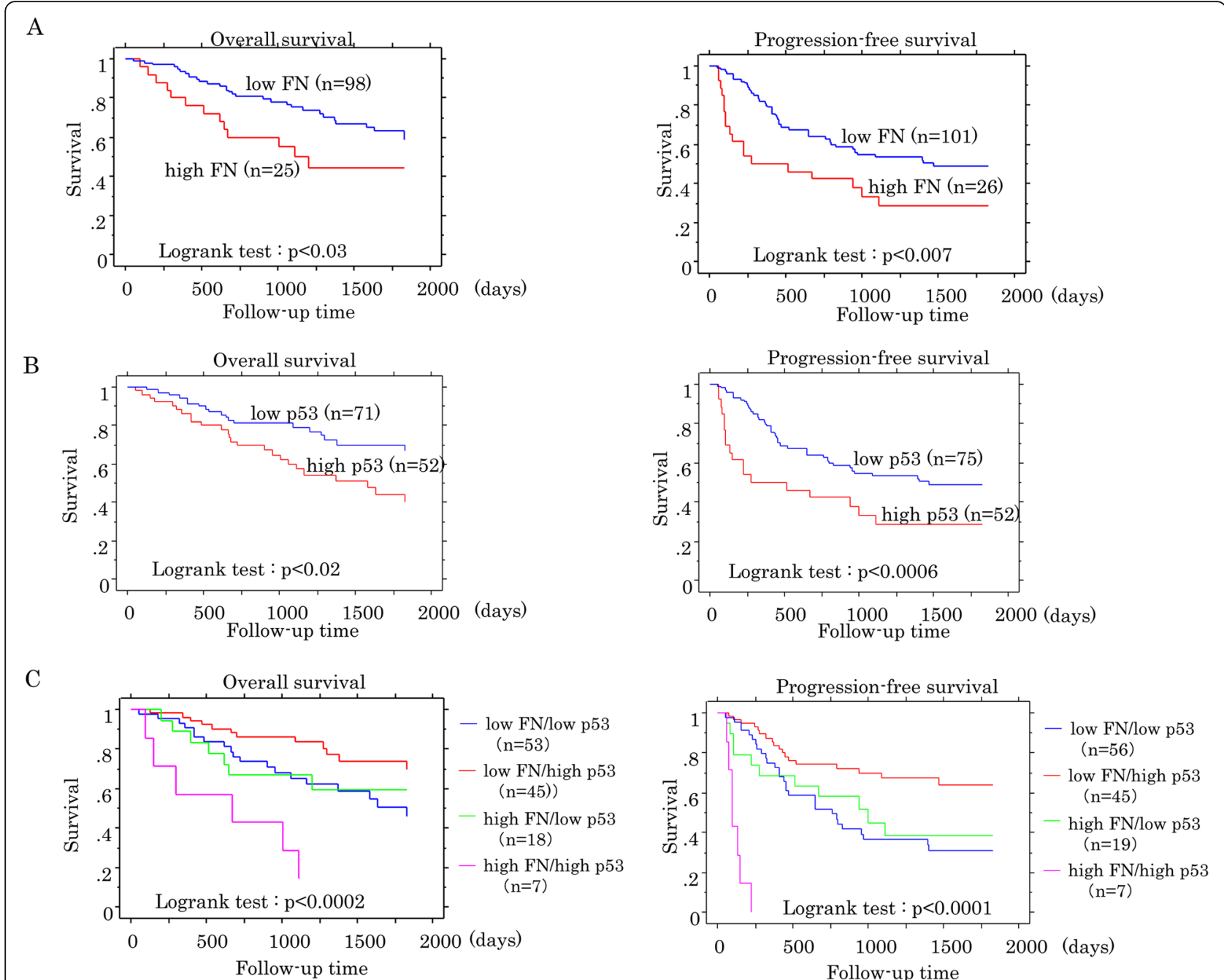

Fig. 8 Relationship between FN and p53 expression and prognosis in OCCCa/OHGSeCa. OS (left) and PFS (right) relative to FN (a), p53 (b), and combined FN and p53 expression (c) in OCCCa/OHGSeCa. N, number of cases

OCCCa that have the HNF-1 $\beta+/ p 53+/ A R I D 1 A+$ immunophenotype. However, analysis of the TCGA database revealed that expression of $H N F 1 \beta$ and ARID1A mRNA was not correlated with p53 status in OHGSeCa. Given the evidence that HNF-1 $\beta$ is a sensitive and specific marker for OCCCa and is not expressed in OHGSeCa with clear cell changes [30], it appears that some cell type-specific factors may also be required for establishment of OHGSeCa with the immunophenotypic features we specify above.

We also found that p53-KD cells have dramatically altered cell morphology and are more fibroblast-like in appearance; these changes are accompanied by increased expression of E-cadherin-repressor Snail, as well as pAkt and pGSK-3 $\beta$, and decreased E-cadherin expression. Although Snail promoter activity was specifically repressed by p53wt, we did not observe differences in Snail mRNA levels between p53-KD and the mock-transfected cells.
In general, Snail expression is decreased through GSK$3 \beta$-mediated phosphorylation/degradation [31], while GSK-3 $\beta$ activity is inhibited following activation of Akt [32]. Given the mutual antagonism between the p53 and Akt networks [33-35], it is suggested that loss of p53 function leads to post-translational upregulation of Snail through activation of the Akt/GSK-3 $\beta$ axis, which in turn leads to induction of EMT. Interestingly, p53mt can directly bind and trans-repress the promoter of $m i R$ $130 b$, a microRNA that specifically downregulates ZEB1, leading to the upregulation of BMI-1 and Snail [36]. In addition, p53wt can induce MDM2 mediated degradation of Snail [37].

Here, we found that p53-KD cells had a reduced proliferative rate and enhanced migration capability, along with enhanced G2/M arrest and increased p27 $7^{\text {kip1 }}$ expression. Moreover, cyclin B1 expression also decreased progressively after serum stimulation in p53-KD cells. 
Table 3 Univariate and multivariate anayses for overall survival and progression-free survival in OCCCa/OHGSeCa

\begin{tabular}{|c|c|c|c|c|c|c|c|c|c|}
\hline \multicolumn{5}{|l|}{ Univariate analysis } & \multicolumn{5}{|l|}{ Multivariate analysis } \\
\hline Variables & Cutt-off & Log rank c2 & p-value & factor & Variable & Cut-off & Hazard Ratio & $95 \% \mathrm{Cl}$ & p-value \\
\hline \multicolumn{5}{|l|}{ Overall survival } & \multicolumn{5}{|l|}{ Overall survival } \\
\hline Fibronectin & $2 / 3$ & 4.9 & 0.02 & High score & Fibronectin & $2 / 3$ & 2.6 & $1.2-5.4$ & 0.01 \\
\hline p53 & $5 / 6$ & 6.4 & 0.01 & High score & p53 & $5 / 6$ & 0.9 & $0.4-2.0$ & 0.8 \\
\hline Histological type & OCCCa/OHGSeCa & 11.2 & 0.0008 & OHGSeCa & Histological type & OCCCa/OHGSeCa & 0.4 & $0.2-1.1$ & 0.07 \\
\hline Age & $57 / 58$ & 0.4 & 0.52 & & FIGO stage & $|/\|\quad\|| \mid V$ & 0.2 & $0.06-0.7$ & 0.01 \\
\hline FIGO stage & $|/||\quad||| \quad V$ & 16.1 & $<0.0001$ & $\|\quad\| I \quad I V$ & LN metastasis & $-/+$ & 0.8 & $0.4-1.5$ & 0.5 \\
\hline Tumor size & $11.1 / 11.2$ & 1.1 & 0.3 & & Distant metastasis & $-/+$ & 0.7 & $0.3-1.6$ & 0.4 \\
\hline LN metastasis & $-/+$ & 7.8 & 0.005 & + & Residual tumor & Present/absent & 0.6 & $0.3-1.2$ & 0.2 \\
\hline Distant metastasis & $-/+$ & 8.9 & 0.002 & + & after surgery & & & & \\
\hline $\begin{array}{l}\text { Residual tumor } \\
\text { after surgery }\end{array}$ & Present/absent & 8.1 & 0.004 & Present & & & & & \\
\hline \multicolumn{5}{|c|}{ Progression-free survival } & \multicolumn{5}{|c|}{ Progression-free survival } \\
\hline Fibronectin & $2 / 3$ & 7.6 & 0.006 & High score & Fibronectin & $2 / 3$ & 3.3 & $1.7-6.4$ & 0.0005 \\
\hline p53 & $5 / 6$ & 12.2 & 0.0005 & High score & p53 & $5 / 6$ & 1.3 & $0.6-2.8$ & 0.6 \\
\hline Histological type & OCCCa/OHGSeCa & 16.6 & $<0.0001$ & OHSeGCa & Histological type & OCCCa/OHGSeCa & 0.6 & $0.3-1.3$ & 0.2 \\
\hline Age & $57 / 58$ & 3.9 & 0.04 & $58 \leqq$ & Age & $57 / 58$ & 0.8 & $0.4-1.3$ & 0.3 \\
\hline FIGO stage & $|/||\quad||| V$ & 32.7 & $<0.0001$ & $\|\quad\| I \mid I V$ & FIGO stage & $|/||\quad||| \quad V$ & 0.2 & $0.06-0.5$ & 0.001 \\
\hline Tumor size & $11.1 / 11.2$ & 0.7 & 0.3 & & LN metastasis & $-/+$ & 0.7 & $0.4-1.2$ & 0.2 \\
\hline LN metastasis & $-/+$ & 14.5 & 0.0001 & + & Distant metastasis & $-1+$ & 0.5 & $0.2-0.9$ & 0.03 \\
\hline Distant metastasis & $-/+$ & 22.1 & $<0.0001$ & + & Residual tumor & Present/absent & 0.7 & $0.4-1.3$ & 0.3 \\
\hline $\begin{array}{l}\text { Residual tumors } \\
\text { after surgery }\end{array}$ & Present/absent & 10 & 0.001 & Present & after surgery & & & & \\
\hline
\end{tabular}

$L N$ lymph node, $n$ number of cases

Our findings are consistent with those of previous reports. First, p2 ${ }^{\text {kip } 1}$ is important for the initial activation of $\mathrm{G} 2 / \mathrm{M}$ checkpoint in response to low-dose ionizing radiation [38], in line with evidence that Cdc2, which is essential for entry into mitosis, physically interacts with, and is inhibited by p27 ${ }^{\mathrm{kip} 1}[39,40]$. In addition, binding of $\mathrm{Cdc} 2$ to cyclin $\mathrm{B} 1$ is required for its activity and repression of cyclin $\mathrm{B} 1$ contributes to blocking entry into mitosis. Second, hematopoietic cells expressing p53wt arrest in both G1 and G2 phase of the cell cycle, while p53-null cells or cells overexpressing p53mt exhibited only G2 arrest [41]. Third, reduced levels of p53 correlate with increased $\mathrm{G} 2 / \mathrm{M}$ phase arrest in response to paclitaxel treatment in normal human fibroblast depleted of functional p53 [42]. Finally, migratory cells have a lower proliferation rate in comparison with cells in the tumor core, indicating an inverse correlation between cell proliferation and mobility [43-45].

Our findings also revealed that susceptibility to apoptosis in response to CDDP treatment was significantly inhibited in p53-KD cells. This may be explained by the prolonged high levels of pAkt in response to loss of p53 function, because there is an 'all-or-none' switching behavior between a pro-survival cellular state (low p53 and high Akt levels) and a pro-apoptotic state (high p53 and low Akt levels) [33], as well as decreased expression of the pro-apoptotic protein, bax [46].

An important finding in this study was that FN1 mRNA and protein expression were significantly increased in p53-KD cells, while FN1 promoter activity was repressed by p53wt, but not p53mt, in line with other studies [47, 48]. Moreover, treatment of OCCCa cells with FN resulted in an enhanced migration capability and a reduced proliferation rate. In contrast, the effects of FN on cell morphology, expression of EMTrelated molecules, and susceptibility to apoptosis were minimal. Taken together with our results that p53-KD increases the expression of the FN receptors integrins $\beta 1, \beta 2$, and $\beta 3$ [49], we conclude that FN upregulation due to loss of p53 function is closely associated with enhancement of cell mobility, but not induction of EMT and apoptotic features. However, we could not demonstrate a direct correlation between FN and p53 scores in the OCCCa/OHGSeCa category, indicating that a p53independent pathway must regulate $\mathrm{FN}$ expression in the tumors, particularly in OCCCa. In fact, FN 


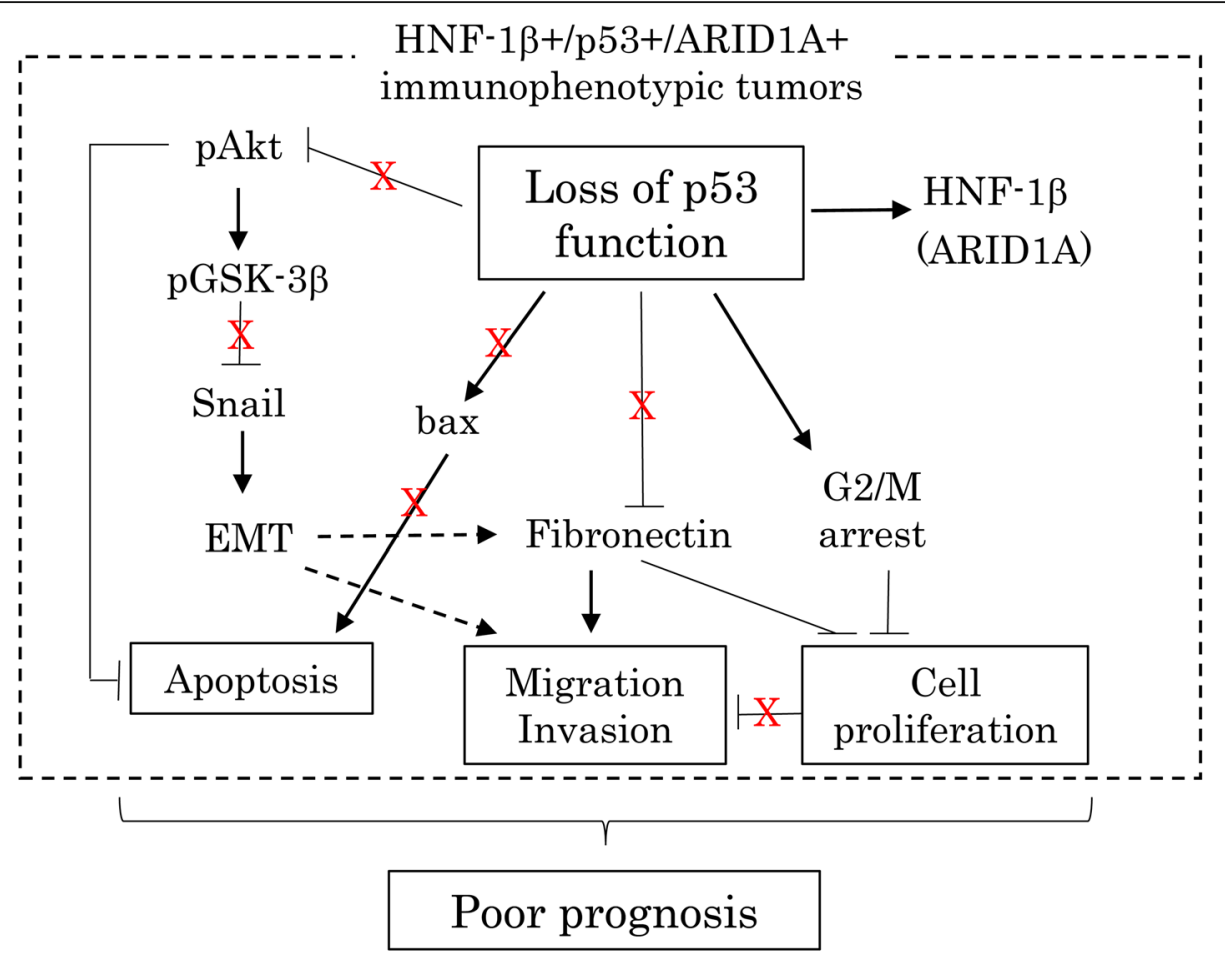

\section{$\mathrm{X}$ : inhibition of the pathway}

Fig. 9 Schematic representation of the interplay between the p53 pathway, FN expression, and the Akt/GSK-3ß/Snail axis in the aggressive OCCCa/OHGSeCa

expression is upregulated through the PI3K/Akt pathway in tamoxifen-resistant breast cancer cells [50].

Finally, patients with a combination of high FN and high p53 IHC scores had significantly worse OS and PFS than did patients with low values for both scores in OCCCa/ OHGSeCa. Both FN and p53 scores were also significantly associated with several unfavorable clinicopathological factors in the tumors. Moreover, multivariate Cox regression analysis also showed that FN, but not p53, was a significant and independent unfavorable prognostic factor for OS and PFS. Furthermore, there was a positive association between high FN score, enlarged tumor size and nodal metastasis, suggesting that combined IHC analysis for $\mathrm{FN}$ and $\mathrm{p} 53$ expression may have great utility in $\mathrm{OCCCa} / \mathrm{OHGSeCa}$ prediction and prognosis.

\section{Conclusion}

Upregulation of FN following loss of p53 function may influence the malignant properties of OCCCa/OHG$\mathrm{SeCa}$, particularly in those tumors with an HNF-1 $\beta+$ / p53+/ARID1A+ immunophenotype. The accompanying induction of EMT/CSC properties and inhibition of apoptosis due to p53 abnormalities also contribute to the establishment and maintenance of tumor phenotypic characteristics (Fig. 9).

\section{Supplementary information}

Supplementary information accompanies this paper at https://doi.org/10 1186/s12964-020-00580-3.

Additional file 1 : Supplementary Figure $\mathbf{S 1}$ p53, HNF-1 $\beta$, and ARID1A expression in OCCCa cells. (A) Western blot analysis for the indicated proteins in total lysates from four OCCCa cell lines. Note p53 mutation was only presented in ES-2 cells. wt, wild-type. (B) Analysis of TCGA data for associations between $p 53$ gene abnormalities with expression of HNF-1 $\beta$ and ARIDIA mRNAs (left and right, respectively).

Additional file $\mathbf{2}$ : Supplementary Figure S2 FN and p53 expression in OECa. (A) FN and p53 scores in OECa. (B) FN/p53 IHC scores in the immunoprofile groups (IPGs) of OECa including OCCCa, OHGSeCa, OLGSeCa, OEmCa, and OMuCa. OMuCa are excluded from IPG VII (w/o OMuCa). The data shown are as means \pm SDs.

Additional file $\mathbf{3}$ : Supplementary Figure S3 Relationship between FN and p53 expression and prognosis in OCCCa or OHGSeCa. (A) OS (left) and PFS (right) relative to FN and p53 expression (upper and lower, respectively) in OCCCa. B) OS (left) and PFS (right) relative to FN and p53 expression (upper and lower, respectively) in OHGSeCa. N, number of cases.

\section{Abbreviations}

OECa: Ovarian epithelial carcinomas; OHGSeCa: Ovarian high grade serous carcinoma; OCCCa: Ovarian clear cell carcinoma; KD: Knockdown;

p53wt: Wild-type p53; p53mt: Mutant type p53; IHC: Immunohistochemistry; EMT: Epithelial-mesenchymal transition; FN: Fibronectin; OS: Overall survival; PFS: Progression-free survival; IPG: Immunoprofile group 


\section{Authors' contributions}

AY, TM, and MS carried out the majority of the experiments, analyzed the data, and wrote the manuscript. They were helped by $\mathrm{YO}, \mathrm{YH}, \mathrm{MT}$, and MN. All authors reviewed and approved the final manuscript.

\section{Funding}

This study was supported by a grant from JSPS KAKENHI Grant Number 17 K08703.

\section{Availability of data and materials}

Data and materials will be shared.

\section{Ethics approval and consent to participate}

Approval for this study was given by the Ethics Committee of the Kitasato University School of Medicine (B16-10).

\section{Consent for publication}

Not applicable.

\section{Competing interests}

The declare that they have no competing interest.

\section{Author details}

'Department of Pathology, Kitasato University School of Medicine, 1-15-1 Kitasato, Minami-ku, Sagamihara, Kanagawa 252-0374, Japan. ${ }^{2}$ Department of Applied Genomics, Kazusa DNA Research Institute, Laboratory of Clinical Omics Research, 2-6-7 Kazusakamatari, Kisaratsu, Chiba 292-0818, Japan.

Received: 29 January 2020 Accepted: 13 April 2020

Published online: 07 July 2020

\section{References}

1. Jemal A, Siegel R, Ward E, Murray T, Xu J, Thun MJ. Cancer statistics, 2007. CA Cancer J Clin. 2007:57:43-63.

2. Wang $Y$, Helland A, Holm R, Skomedal H, Abeler VM, Danielsen HE, Trope CG, Borresen-Dale A-L, Kristensen GB. TP53 mutations in early-stage ovarian carcinoma, relation to long-term survival. Br J Cancer. 2004;90:678-85.

3. Salani R, Backes FJ, Fung MF, Holschneider CH, Parker LP, Bristow RE, Goff BA. Posttreatment surveillance and diagnosis of recurrence in women with gynecologic malignancies: Society of Gynecologic Oncologists recommendations. Am J Obstet Gynecol. 2001;204:466-78.

4. Hollstein M, Sidransky D, Vogelstein B, Harris CC. p53 mutations in human cancers. Science. 1991;253:49-53.

5. Bieging KT, Mello SS, Attardi LD. Unravelling mechanisms of p53-mediated tumor suppression. Nat Rev Cancer. 2014:14:359-70.

6. Muller PA, Vousden KH. p53 mutations in cancer. Nat Cell Biol. 2013;15:2-8

7. Brosh $R$, Rotter $V$. When mutants gain new powers: news from the mutant p53 field. Nat Rev Cancer. 2009;9:701-13.

8. Bernardini MQ, Baba T, Lee PS, Bamett JC, Sfakianos GP, Secord AA, Murphy SK, Iversen E, Marks JR, Berchuck A. Expression signature of TP53 mutations in serous ovarian cancers. BMC Cancer. 2010;10:237.

9. Piek JM, van Diest PJ, Zweemer RP, Jansen JW, Poort-Keesom RJ, Menko FH, Gille JJ, Jongsma AP, Pals G, Kenemans P, Verheijien RH. Dysplastic changes in prophylactically removed fallopian tubes of women predisposed to developing ovarian cancer. J Pathol. 2001;195:451-6.

10. Lee Y, Miron A, Drapkin R, Nucci MR, Medeiros F, Saleemuddin A, Garber J, Birch C, Mou H, Gordon RW, Cramer DW, McKeon FD, Crum CP. A candidate precursor to serous carcinoma that originates in the distal fallopian tube. Pathol. 2007;211:26-35.

11. Carlson JW, Miron A, Jarboe EA, Parast MM, Hirsch MS, Lee Y, Muto MG, Kindelberger D, Crum CP. Serous tubal intraepithelial carcinoma: its potential role in primary peritoneal serous carcinoma and serous cancer prevention. J Clin Oncol. 2008;26:4160-5.

12. Yokoi A, Matsumoto T, Watanabe G, Tochimoto M, Saegusa M. Immunophenotypic profile as a predictor of prognosis in advanced ovarian carcinoma. Hum Pathol. 2019;85:210-20

13. Akiya M, Yamazaki M, Matsumoto T, Kawashima Y, Oguri Y, Kajita S, Kijima D, Chiba R, Yokoi A, Takahashi H, Kodera Y, Saegusa M. Identification of LEFTY as a molecular marker for ovarian clear cell carcinoma. Oncotarget. 2017;8: 63646-64.
14. Seagusa M, Hashimura M, Kuwata T, Hamano M, Okayasu I. $\beta$-Catenin simultaneously indices activation of the p53-p21WAF1 pathway and overexpression of cyclin D1 during squamous differentiation of endometrial carcinoma cells. Am J Pathol. 2004;164:1739-49.

15. Seagusa M, Hashimura M, Kuwata T, Hamano M, Okayasu I. Crosstalk between NF-kB/p65 and $\beta$-catenin/TCF4/p300 signalling pathways through alterations in GSK-3 $\beta$ expression during trans-differentiation of endometrial carcinoma cells. J Pathol. 2007;213:35-45.

16. Suzuki E, Kajita S, Takahashi H, Matsumoto T, Tsuruta T, Saegusa M. Transcriptional upregulation of HNF-1 $\beta$ by NF-KB in ovarian clear cell carcinoma modulates susceptibility to apoptosis through alteration in bcl-2 expression. Lab Investig. 2015;95:962-72.

17. Matsumoto T, Yokoi A, Hashimura M, Oguri Y, Akiya M, Saegusa M. TGF- $\beta$ mediated LEFTY/Akt/GSK-3ß/snail axis modulates epithelial-mesenchymal transition and cancer stem cell properties in ovarian clear cell carcinomas. Mol Carcinog. 2018:57:957-67.

18. Kerr JF, Winterford CM, Harmon BV. Apoptosis: its significance in cancer and cancer therapy. Cancer. 1994;73:2013-26.

19. Aders S, Huber W. Differential expression analysis for sequence count data. Genome Biol. 2010;11:R106.

20. Longacre TA, Wells M, Bell DA, Malpica A, Prat J, Ronnet BM. Tumours of the tumours of the ovary. In: Kurman RJ, Carcangiu ML, HerringtonCS, Young $\mathrm{RH}$, editors. WHO Classification of Tumours of Female Reproductive Organs. Lyon: IARC; 2014. p. 11-86.

21. Yemelyanova A, Vang R, Kshirsagar M, Lu D, Marks MA, Shih le M, Kurman RJ. Immunohistochemical staining patterns of p53 can serve as a surrogate marker for TP53 mutations in ovarian carcinomas: an immunohistochemical and nucleotide sequencing analysis. Mod Pathol. 2011;24:1248-53.

22. Mani SA, Guo W, Liao MJ, Eaton EN, Ayyanan A, Zhou AY, Brooks M, Reinhard F, Zhang CC, Shipitsin M, Campbell LL, Polyak K, Brisken C, Yang J, Weinberg RA. The epithelial-mesenchymal transition generates cells with properties of stem cells. Cell. 2008;133:704-15.

23. Park J, Schwarzbauer JE. Mammary epithelial cell interactions with fibronectin stimulate epithelial-mesenchymal transition. Oncogene. 2014;33: 1649-57.

24. Li C-L, Yang D, Cao X, Wang F, Hong D-Y, Wang J, Shen X-C, Chen Y. Fibronectin induces epithelial-mesenchymal transition in human breast cancer MCF-7 cells via activation of calpain. Oncol Lett. 2017; 13:3889-95.

25. Jiang D, Dumur Cl, Massey HD, Ramakrishan V, Subler MA, Windle JJ. Comparison of effect of p53 null and gain-of-function mutations on salivary tumors in MMTV-Hras transgenic mice. PLoS One. 2015;10:e0118029.

26. Jackson EL, Olive KP, Tuveson DA, Bronson R, Crowley D, Brown M, Jacks T. The differential effects of mutant p53 alleles on advanced murine lung cancer. Cancer Res. 2005;65:10280-8.

27. Wijnhoven SW, Zwart E, Speksnijder EN, Beems RB, Olive KP, Tuveson DA, Jonkers J, Schaap MM, van den Berg J, Jacks T, van Steeg H, de Vries A. Mice expressing a mammary gland-specific R270H mutation in the p53 tumor suppressor gene mimic human breast cancer development. Cancer Res. 2005:65:8166-73.

28. Liu G, McDonnell TJ, Montes de Oca Luna R, Kapoor M, Mims B, El-Naggar AK, Lozano G. High metastatic potential in mice inheriting a targeted p53 missense mutation. Proc Natl Acad Sci USA. 2000;97:4174-9.

29. Kim MP, Zhang Y, Lozano G. mutant p53: multiple mechanisms define biologic activity in cancer. Front Oncol. 2015;5:249.

30. DeLair D, Han G, Irving JA, Leung S, Ewanowich CA, Longacre TA, Gilks CB, Soslow RA. HNF-1 $\beta$ in ovarian carcinomas with serous and clear cell change. Int J Gynecol Pathol. 2013:32:541-6.

31. Zhou BP, Deng J, Xia W, Xu J, Li YM, Gunduz M, Hung MC. Dual regulation of snail by GSK-3ß-mediated phosphorylation in control of epithelialmesenchymal transition. Nat Cell Biol. 2004;6:931-40.

32. Lin JX, Xie XS, Weng XF, Qiu SL, Xie JW, Wang JB, Lu J, Chen QY, Cao LL, Lin $M$, Tu RH, Li P, Huang CM, Zheng CH. Overexpression of IC53d promotes the proliferation of gastric cancer cells by activating the AKT/GSK-3ß/cyclin D1 signaling pathway. Oncol Rep. 2019;41:2739-52.

33. Wee KB, Aguda BD. Akt versus p53 in a network of oncogenes and tumor suppressor genes regulating cell survival and death. Biophys J. 2006;91:857-65.

34. Wee KB, Surana U, Aguda BD. Oscillations of the p53-Akt network: implications on cell survival and death. PLoS One. 2009;4:e4407. 
35. Gottlieb TM, Leal JFM, Seger R, Taya Y, Oren M. Cross-talk between Akt, p53 and Mdm2: possible implications for the regulation of apoptosis. Oncogene. 2002;21:1299-303.

36. Dong P, Karaayvaz M, Jia N, Kaneuchi M, Hamada J, Watari H, Sudo S, Ju J, Sakuragi N. Mutant p53 gain-of-function induces epithelial-mesenchymal transition through modulation of the miR-130b-ZEB1 axis. Oncogene. 2013; 32:3286-95.

37. Lim S-O, Kim H, Jung G. p53 inhibits tumor cell invasion via the degradation of snail protein in hepatocellular carcinoma. FEBS Lett. 2010;584:2231-6.

38. Payne SR, Zhang S, Tsuchiya K, Moser R, Gurley KE, Longton G, DeBoer J, Kemp CJ. p2 $7^{\text {kip } 1}$ deficiency impairs $G_{2} / M$ arrest in response to DNA damage leading to an increase in genetic instability. Mol Cell Biol. 2008;28: 258-68.

39. Nurse P. Universal control mechanism regulating onset of $\mathrm{M}-$ phase. Nature. 1990;344:503-8

40. Nakayama K, Nagahama H, Minamishima A, Miyake S, Ishida N, Hatakeyama S, Kitagawa M, lemura S, Natsume T, Nakayama Kl. Skp2-mediated degradation of p27 regulates progression into mitosis. Dev Cell. 2004;6:661-72.

41. Kastan MB, Onvekwere O, Sidransky D, Vogelstein B, Craig RW. Participation of p53 protein in the cellular response to DNA damage. Cancer Res. 1991; 51:6304-11.

42. Wahl AF, Donaldson KL, Faircnild C, Lee FYF, Foster SA, Demers GW, Galloway DA. Loss of normal p53 function confers sensitization to Taxol by increasing G2/M arrest and apoptosis. Nat Med. 1996;2:72-9.

43. Giese A, Loo MA, Tran N, Haskett D, Coons SW, Berens ME. Dichotomy of astrocytoma migration and proliferation. Int J Cancer. 1996;67:275-82.

44. Giese A, Bjerkvig R, Berens ME, Westphal M. Cost of migration: invasion of malignant glioma and implications for treatment. J Clin Oncol. 2003;21: 1624-36.

45. Merzak A, McCrea S, Koocheckpour S, Pilkington GJ. Control of human glioma cell growth, migration and invasion in vitro by transforming growth factor beta 1. Br J Cancer. 1994;70:199-203.

46. Pawloaski J, Kraft AS. Bax-induced apoptotic cell death. Proc Natl Acad Sci U S A. 2000;97:529-31.

47. Iotsova V, Stehelin D. Down-regulation of fibronectin gene expression by the p53 tumor suppressor protein. Cell Growth Differ. 1996;7:629-34.

48. You D, Jung SP, Jeong Y, Bae SY, Kim S. Wild-type p53 controls the level of fibronectin expression in breast cancer cells. Oncol Rep. 2017;38:2551-7.

49. Wang JP, Hielscher A. Fibronectin: how its aberrant expression in tumors may improve therapeutic targeting. J Cancer. 2017;8:674-82.

50. You D, Jung SP, Jeong Y, Bae SY, Lee JE, Kim S. Fibronectin expression is upregulated by PI-3K/Akt activation in tamoxifen-resistant breast cancer cells. BMB Rep. 2017;50:615-20

\section{Publisher's Note}

Springer Nature remains neutral with regard to jurisdictional claims in published maps and institutional affiliations.

Ready to submit your research? Choose BMC and benefit from:

- fast, convenient online submission

- thorough peer review by experienced researchers in your field

- rapid publication on acceptance

- support for research data, including large and complex data types

- gold Open Access which fosters wider collaboration and increased citations

- maximum visibility for your research: over $100 \mathrm{M}$ website views per year

At BMC, research is always in progress.

Learn more biomedcentral.com/submissions 